\title{
The effect of entrepreneurial orientation on Bangladeshi SME performance: Role of organiza- tional culture
}

Abu Shams Mohammad Mahmudul Hoque ${ }^{a^{*}}$

${ }^{a}$ School of Business, Primeasia University, Dhaka, Bangladesh

\section{A B S T R A C T}

\begin{abstract}
This study explores the role of organizational culture (OC) in the relationship between entrepreneurial orientation (EO) and Bangladeshi small and medium enterprises (SMEs) performance. Their relationship obtains a substantial scholarly attention, however very few empirical studies have been conducted among Bangladeshi SMEs. Generally, SMEs contribute to the economy through employment generation, poverty reduction, innovation, social cohesion, and so on, which in turn contribute to the growth domestic product (GDP) of Bangladesh. Hence, SMEs are considered as a key reactor of economic growth in Bangladesh. Grounded on the literature and theoretical fact, a model was developed and intended to examine this relationship. A quantitative survey technique was exercised and the data were collected from the randomly selected 384 owners of SMEs in Dhaka-Bangladesh. The data were analyzed by using SEM-AMOS. Based on the statistical results, EO and OC were significantly related to SME performance and OC was found to mediate the relationship between EO and SME performance. This study will help entrepreneurs as well as policy makers make better decisions for maximizing SME performance through improving OC in the competitive global economy.
\end{abstract}

\section{Introduction}

SME is well known as a source of economic liberty around the world (Hoque \& Awang, 2016a). Hence, Bangladeshi government has accepted SMEs as a foremost segment (Hoque, Awang, \& Salam, 2017a, Hoque \& Awang, 2016a). In spite of this, in reality, SMEs' support to Bangladeshi GDP is fluctuating due to inadequate SME performance (Hoque et al., 2017a; Chowdhury et al., 2013). The causes of inadequate and inconsistent performance of Bangladeshi SMEs are lack of finance, inappropriate entrepreneurial behavior, improper marketing strategy, and weak relationship with customers (Hoque et al., 2017a; Alauddin \& Chowdhury, 2015; Bangudu, 2013). In addition, survival and better SME performance depend on the encouraging policy, better organizational culture (OC) as well as entrepreneurial ability that can drive and develop the SME sector of a country (Obaji \& Olugu, 2014).

\footnotetext{
* Corresponding author.

E-mail address: drshams369@gmail.com (A. S. M. M. Hoque)

(C) 2018 by the authors; licensee Growing Science, Canada. doi: $10.5267 /$ j.ijdns.2018.7.001
} 
More importantly, Bangladesh has fall flat to achieve maximum benefit and superior SME performance (Ahmed, 2001). Henceforth, it is vital to scrutinize the complications of Bangladeshi SME sector and take appropriate steps so that the weak SMEs will accomplish better performance and also gain sustainable growth. In this regard, this study will try to explore the effect of entrepreneurial orientation (EO) on Bangladeshi SME performance and to scrutinize the mediating role of OC on the connection between EO and Bangladeshi SME performance. Wales et al. (2011) claimed that most of EO studies were conducted in Europe \& USA and suggested for further research across different countries. Nevertheless, to the best of our knowledge, none has empirically assessed the mediating role of OC on EO and Bangladeshi SME performance relationship. Consequently, this study endeavors to minimize the research gap and to show future research paths on SME performance.

\section{Literature Review}

\subsection{Study Context}

SMEs represent $99.85 \%$ of the total business entities in Bangladesh, totaling to six million active establishments, and they are acting as the backbone of Bangladeshi economy (Hoque et al., 2018e; Hoque \& Awang, 2016b). Conceivably it is why, the Government of Bangladesh works closely with developmental organizations in order to improve the socio-economic status, as well as enhancing economic growth via facilitating SME establishment and boosting entrepreneurial activities in Bangladesh. As SMEs are a prime concern for the government, it is therefore that this study aimed on SMEs in Bangladesh.

\subsection{Entrepreneurial Orientation}

Entrepreneurial orientation has become a key issue of entrepreneurship research for the last 40 years (Covin \& Wales, 2012). Covin \& Wales (2012) mentioned that the origins of EO research can be traced to the work of Mintzberg (1973). Whereas et al. (1995) mentioned in their study that Child (1972) forwarded the origins of entrepreneurial orientation from a strategic-choice perspective. Later, Lumpkin \& Dess (1996) further articulated that EO could be defined as processing, practicing, and decision-making actions that lead to such new entries. According to Pearce et al. (2010) EO is a set of distinct but associated behaviors that have the qualities of pro-activeness, innovativeness, risk taking, competitive aggressiveness, and autonomy. On the other hand, Hoque et al. (2018e) mentioned that EO indicates firm's ability of innovation and pro-activeness in order to satisfy prospective customer needs, through discoveries new products or services, leveraging resources and by taking risk before its competitors. Similarly, Miller (1983) defines EO as a function of an entrepreneurial firm involves in product marketing innovation, commences risky ventures, and is first to come up with proactive innovations. According to Wiklund and Shepherd (2003) EO can expedite a firm's action and thereby aid them to be ahead of the competition and more often, EO is regarded as a higher order construct, and each dimension of EO construct (i.e. proactiveness, innovativeness, risk-taking, and resource-leveraging) may have a different relation to the performance variables (Hoque et al., 2018e; Zeebaree \& Siron, 2017). Thus, EO is one of the important resources that influence SME's performance.

\subsection{Dimensions of Entrepreneurial Orientation (EO)}

According to Beattie (2016) and Richard et al. (2004), EO has been conceptualized in existing literature as having three to five dimensions, which may vary independently. However, three (3) dimensions of EO have been commonly used in the literature: innovativeness, pro-activeness, and risk taking but there exists one more component that is resource-leveraging which has been identified based on early theories (i.e. Resource Based Theory and Resource Advance Theory) (Hoque et al., 2018e) and have been considered as additional and significant component to the EO construct. 


\subsubsection{Innovativeness}

Innovativeness indicates pursuing and giving support to uniqueness, creative methods and the advancement of new ideas through testing (Schumpeter, 1942). Innovativeness is a significant factor to characterize entrepreneurship which could be described as the efforts to discover new opportunities and which comprise experimentation and creativity that results in new products and services, or and enhanced technical traits of existing services and products (Mahmood \& Hanafi, 2013; Hoque et al., 2018e).

\subsubsection{Pro-activeness}

Innovativeness indicates pursuing and giving support to uniqueness, creative methods and the advancement of new ideas through testing (Schumpeter, 1942). Innovativeness is a significant factor to characterize entrepreneurship which could be described as the efforts to discover new opportunities and which comprise experimentation and creativity that results in new products and services, or and enhanced technical traits of existing services and products (Hoque et al., 2018e, Mahmood \& Hanafi, 2013).

\subsubsection{Risk Taking}

According to Rauch et al. (2009) risk-taking, is associated with undertaking certain activities of assigning valuable resources to venture capitals in changeable environments. According to Lumpkin and Dess (1996) risk-taking is normally perceived as a trait more often exercised to describe entrepreneurship. Hoque et al. (2018e) stated that risk-taking implies to the degree to which entrepreneurs are eager to make large resource commitments.

\subsubsection{Resource-leveraging}

According to Hoque et al. (2018e) resource-leveraging denotes analytically measuring the use of available resources, detecting the requirement for additional resources, or creating new resources to address identified needs. Hence, entrepreneurs need to orient with resource-leveraging as according to Nijssen (2017); Hoque and Awang (2016a); Morgan et al. (2004) resource-leveraging is internal and external resources using ability to achieve the vendors target. Whereas, Hoque et al. (2018e) and Yang (2018) claimed that resource-leveraging indicates achieving more with less resources through the skillful arrangement of them.

\subsection{SME Performance}

Performance is a latent construct which is having different meaning in the academic literature. Every definition emphasizes different views, methods, and features as a result there is no single established explanation of performance. Generally, SME performance expresses the results of a firm's activities by shouldering a complicated series of actions (Don, 2006). According to Obiwuru et al. (2011) performance pronounces, how good a firm is carrying out. Hoque and Awang (2019) defined performance measurement as a branded system with a set of metrics used to quantify the effectiveness and efficiency of firm's actions. SME performance is deemed to be the outcome of constructive management activities and it can be assessed exploiting a number of norms; which comprises efficiency, effectiveness, productivity, and growth (Mandy (2009). Actually, SME performance is the working ability to accomplish the desires of a firm's stakeholders (Smith \& Reece, 1999). Hence, performance is the power of a firm to yield satisfactory results and actions (Davood \& Morteza, 2012). Nowadays, high SME performance assists to remove the blockades and generates an extensive opportunity for SME to flourish as well as to compete strongly in the global market (Aminul \& Shariff, 2015). Therefore, the entrepreneurs who are particularly accountable for administering SMEs try to gain better SME performance via new procedures, plan, and strategies during entrepreneurial life cycle (Rugraff \& Hansen, 2011). Performance of SMEs can be measured quantitatively and qualitatively (Hoque \& Awang, 2019; Hussain et al., 2015). In the past studies, performance of SMEs is either measured using subjective or objective variables (Hoque \& 
Awang, 2018; Weimei \& Feng-e, 2012). Whereas, this study used subjective measure of strategic and financial performance as the two dimensions in assessing Bangladeshi SME performance.

\subsection{Organizational culture (OC)}

OC has been described by various academics in various manners. OC can be expressed as an outline of shared basic assumptions that was learned by a group since it resolves its complications of internal incorporation and external acclimatization, that has functioned well enough to be considered valid and consequently, to be imparted to new members as the correct way to think, feel and perceive in perspective to those complications (Tidor et al., 2012; Hoque et al., 2016; Schein, 2004). OC is an enduring set of beliefs, values, and assumptions that portrayed organizations as well as their associates (Cameron \& Quinn, 2006). Thus, OC is deemed to be the mode of life of a firm which distinguish it from its comparable firm. SMEs have a more organic culture than big organizations (Tidor et al., 2012). Generally, SME is smaller in size and small number of people are typically united under common beliefs and values under the head of SME hence, it is comparatively easy for SME to regulate the organizational culture for betterment of SME performance than the large organizations. In the recent world economic crisis there was a bad impact on the performances of maximum number of enterprises all over the world. But the most affected sector was the SME sector. Hence, to avoid future problems and to gain better SME performance, organizational culture must be diagnosed and the change must begin with it (Tidor et al., 2012).

\subsection{Entrepreneurial Orientation and SME Performance}

The role of EO on SME performance has been assessed intensively both empirically and theoretically mostly in Europe and America (Hoque, 2018; Kraus, Rigtering, Hughes, \& Hosman, 2012). Out of those empirical studies most of the studies found that there is a significant and positive relationship exists between EO and SME performance (Hoque \& Awang, 2019; Hoque, 2018; Ibrahim, Keat, \& AbdulRani, 2017; Ibrahim \& Masud, 2016; Al-Dhaafri, Al-Swidi, \& Yusoff, 2016; Kantur, 2016). Nevertheless, some of the studies found either not significant (Hoque, 2018; Kreiser, Marino, Kuratko, \& Weaver, 2013; Hartsfield, Johansen, \& Knight, 2008; Naldi, Nordqvist, Sjoberg, \& Wiklund, 2007; Slater \& Narver, 2000) or mixed relationship between EO and SME performance as the results (Hoque, 2018; Tang, Marino, Zhang, \& Li, 2008; Walter, Aver, \& Ritter, 2006; Swierczek \& Ha, 2003; Covina \& Slevin, 1989). Nonetheless, Lumpkin \& Dess (1996) submitted that the relationship between EO and SME performance is influenced by other factors such as the context of the business, business strategy, organizational culture and many more. Therefore, a number of aspects came into account to explain this linkage. Consequently, a meta-analysis was conducted by Rauch et al. (2009) on EO and SME performance relationship. In their study, most of the articles showed a significant positive relationship between EO and SME performance but only four articles, out of 51 articles mentioned mixed or not significant findings and these articles were written by Walter et al. (2006), Swierczek \& Ha (2003), Slater \& Narver (2000), and Covin \& Slevin (1989). However, Ibrahim et al. (2017); Zhang \& Zhang (2012); Idar \& Mahmood (2011) mentioned in their studies that in some instances, the moderating effect of conformational approach explained the contradictory empirical outcomes on the relationship between EO and SME performance. Nonetheless, Rauch et al. (2009) made an amass concluding remark that an overall significant relationship between EO and SME performance exists and the value of EO might vary. Additionally, Stam \& Elfring (2008) revealed that it is vital for academics to be aware of the context in which EO is exercised by SMEs. So due to the variations in the findings of past studies, this research suggested the following hypothesis:

H1. There is a significant positive effect of entrepreneurial orientation on Bangladeshi SME Performance. 


\subsection{Entrepreneurial Orientation and Organizational culture}

OC is acknowledged as an essential ancestor of entrepreneurial decision making in entrepreneurship research, (Zahra et al., 2004). Since the 1980s, organizational behavioral studies have emphasized the key position of OC for firm's competitive advantage and development (Cameron \& Quinn, 2006; Fiol, 1991). OC acts a starring role of a prospective antecedent that could hamper or encourage the pursuit of entrepreneurial actions as well as to determine organizational success (Goel \& Jones, 2016; Fletcher et al., 2012; Chirico \& Nordqvist, 2010). Not only has the EO and OC been connected to the decision-making activity of SMEs (Mitchell et al., 2000) and Lumpkin \& Dess (1996) claimed that EO affects OC but also OC affects EO which influences the behavior of individuals within organizations and is particularly relevant to entrepreneurship, since main decision originators perform as the intellect of the SME and administer the overall strategic orientation of the organization. The relationship between EO strategy and OC is supported by numerous current studies that have found EO strategy has an appreciable effect on SME's culture (Tihanyi et al., 2005). Hence, this research proposed the following hypothesis:

$\mathrm{H} 2$. There is a significant positive effect of entrepreneurial orientation on organizational culture of Bangladeshi SME.

2.8 Organizational culture (OC), SME Performance and the Mediating Role of OC on EO and SME Performance Relationship

Numerous studies have been accomplished on organizational culture and SME performance and several studies reported significant relationship between the two constructs, whereas other studies reported not significant relationship or mixed findings. According to Xenikuo and Simosi (2006) cultural orientation (CO) has a straight effect on performance. Whereas, Berson et al. (2005) claimed through their study result that OC is a good mediator. Slater et al. (2011) explored that CO had a significant role for generating better performance. Similarly, Mujeeb and Ahmad (2011) empirically assessed the connection between factors of $\mathrm{OC}$ and performance management practices, and stated positive significant connection between factors of OC and performance management practices. Duke and Edet (2012) investigated the relationship between OC and Nigerian governmental organization performance and found that there was a strong association between OC and organizational performance. This finding is not similar to Chow (2012) where he scrutinized the role of OC on firm performance, used of two hundred and forty-three Hong Kong and Taiwanese firm and the findings of this study exposed that $\mathrm{OC}$ act as a mediator variable role.

On the other hand, a number of studies, stated a negative relationship between OC and firm performance. Lo (2012) assessed the organizational performance, organizational culture and managerial capabilities using resource based view as theoretical underpinning. The result of the study showed a negative linkage between both organizational culture and managerial capabilities on firm performance. Similarly, Karyeija (2012) assessed the impact of culture on performance appraisal in Africa and found a negative connotation between culture and performance. Moreover, Zainol (2010) scrutinized cultural circumstances and firm performance of Malay family business and obtained that EO did not act as a mediator on the relationship between cultural circumstances and firm performance. Grounded on the above mixed argument, this research proposed the following hypotheses:

H3: There is a significant positive effect of organizational culture on Bangladeshi SME Performance.

H4: Organizational culture mediates the relationship between entrepreneurial orientation and Bangladeshi SME Performance. 


\subsection{Conceptual Framework}

The research framework as depicted in Fig. 1 has higher order construct (i.e., entrepreneurial orientation) which is having four dimensions (i.e., proactive, innovative, risk-taking, and resource-leveraging) and this will represent SME's valuable resources and capabilities. SMEs performance is the dependent variable, while organizational culture is the mediating variable. This research work intends to use the Resource Based Theory (RBT) as an underpinning theory since the RBT turns out to be one of the most widely used theoretical frameworks to underline the way of utilizing SMEs' resources to gain performance.

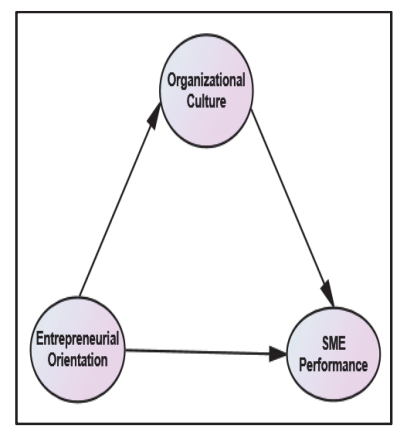

Fig. 1. Research Framework

\section{Research Methodology}

The purpose of this research is to investigate the relationship between EO and SME performance with $\mathrm{OC}$ as a mediator. Therein, perceptions of SME owners were obtained to analyze the relationships. The SMEs established and operating their work in Dhaka, Bangladesh were targeted. In this regard, a selfadministered questionnaire was distributed among the SME owners. A total of 384 usable questionnaires were received back. Grounded on gender of the sample population, male and female represented $57 \%$ and $43 \%$ respectively. For analyzing data, this study uses Structural Equation Modeling (SEM) though IBM-SEM-AMOS software as SEM is a second generation method of multivariate analysis technique (Hoque et al., 2018a; Hoque et al., 2018b).

\subsection{Instrumentation}

From the work of Santos and Brito (2012), this study adapted and customized six (6) items which were grouped into two components, namely strategic performance and financial performance for assessing SME performance construct. For EO construct, this study adapted and customized items from the scale developed by Hoque (2018). Therefore, this study employed a total of twelve (12) items to measure EO as a construct and the items were grouped into four components namely, pro-activeness, innovativeness, risk taking, and resource-leveraging. The direct and mediating effect of organizational culture was measured through six (6) modified and customized items of organization culture assessment instrument developed by Cameron \& Quinn (2006). This study used 5-point interval scale with 1 representing to strongly disagree and 5 as strongly agree for all three constructs.

\section{Results}

\subsection{Measurement Model}

Firstly, the measurement model of the study needs to achieve validity, reliability and unidimensionality (Hoque et al., 2018c; Hoque et al., 2017c; Awang 2015). If the factor loading value for all items are positive with a minimum value of 0.6 , then the unidimensionality will be achieved (Hoque et al., 2017b; Hoque \& Awang, 2016a). Whereas, construct validity will be achieved when the fitness indexes for the measurement model gain three model fit types. For achieving Discriminant validity, it is necessary that 
all constructs of the model are not to be highly correlated. Moreover, if the Average Variance Extracted (AVE) value is 0.5 or more then convergent validity will be achieved (Hoque et al., 2017a). Whereas, if Composite Reliability (CR) and AVE minimum value show 0.6 and 0.5 respectively then construct reliability will be achieved (Awang et at., 2017a; Hoque et al., 2018d; Siddiqui \& Hoque, 2018; Hoque et al., 2017c; Hoque et al., 2017d). The Internal reliability among the items will be achieved when the value of Cronbach Alpha shows the minimum value is 0.7 or more (Hoque \& Awang, 2019; Hoque et al., 2018e; Hoquea \& Awanga, 2016c). The Figure 2 indicate the measurement model of EO, SME performance, and OC latent constructs have met the requirement for unidimensionality as well as construct validity. Table 1 shows factor loading value for every item together with the Cronbach Alpha, CR and AVE for every construct and EO, SME performance \& OC constructs have achieved Internal reliability, Convergent validity, as well as Construct reliability.

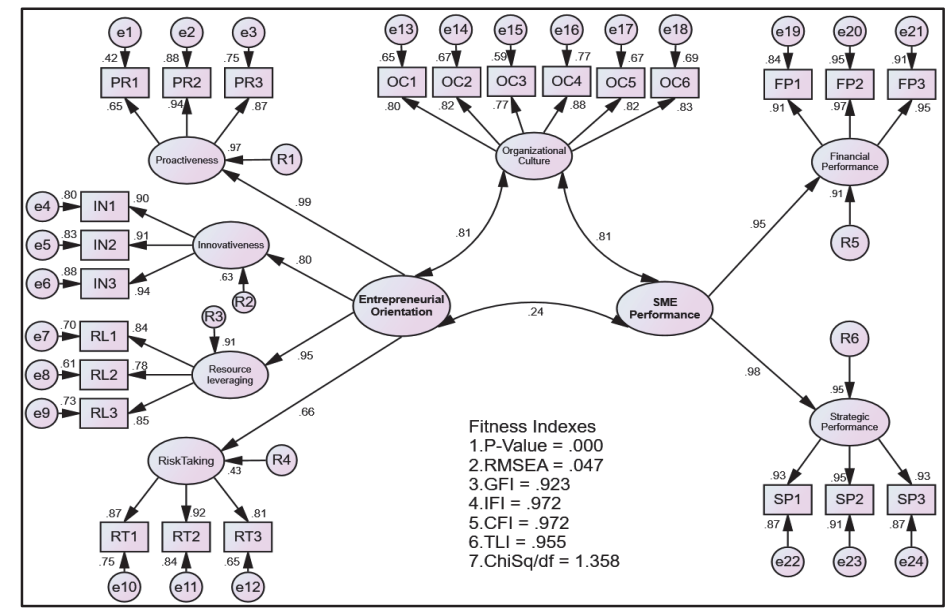

Fig. 2. Pooled CFA Output

Table 1

The CFA Result for the Measurement Model

\begin{tabular}{|c|c|c|c|c|c|}
\hline Variable & Items & $\begin{array}{c}\text { Factor } \\
\text { Loading }\end{array}$ & $\begin{array}{c}\text { Cronbach's Al- } \\
\text { pha }\end{array}$ & $\begin{array}{c}\text { CR } \\
\text { (above 0.6) }\end{array}$ & $\begin{array}{c}\text { AVE } \\
\text { (above 0.5) } \\
\end{array}$ \\
\hline \multirow{4}{*}{$\begin{array}{c}\text { Entrepreneurial Orienta- } \\
\text { tion (EO) }\end{array}$} & Pro-activeness & .99 & \multirow{4}{*}{.916} & \multirow{4}{*}{.917} & \multirow{4}{*}{.740} \\
\hline & Innovativeness & .80 & & & \\
\hline & Resource-leveraging & .95 & & & \\
\hline & Risk Taking & .66 & & & \\
\hline \multirow{3}{*}{ Pro-activeness } & PR1 & .65 & \multirow{3}{*}{.869} & \multirow{3}{*}{.866} & \multirow{3}{*}{.688} \\
\hline & PR2 & .94 & & & \\
\hline & PR3 & .87 & & & \\
\hline \multirow{3}{*}{ Innovativeness } & IN1 & .90 & \multirow{3}{*}{.867} & \multirow{3}{*}{.941} & \multirow{3}{*}{.841} \\
\hline & IN2 & .91 & & & \\
\hline & IN3 & .94 & & & \\
\hline \multirow{3}{*}{ Resource-leveraging } & RL1 & .84 & \multirow{3}{*}{.890} & \multirow{3}{*}{.864} & \multirow{3}{*}{.679} \\
\hline & RL2 & .78 & & & \\
\hline & RL3 & .85 & & & \\
\hline \multirow{3}{*}{ Risk-Taking } & RT1 & .87 & \multirow{3}{*}{.849} & \multirow{3}{*}{.901} & \multirow{3}{*}{.753} \\
\hline & RT2 & .92 & & & \\
\hline & RT3 & .81 & & & \\
\hline \multirow{6}{*}{$\begin{array}{c}\text { Organizational Culture } \\
\text { (OC) }\end{array}$} & $\mathrm{OC} 1$ & .80 & \multirow{6}{*}{.847} & \multirow{6}{*}{.925} & \multirow{6}{*}{.674} \\
\hline & $\mathrm{OC} 2$ & .82 & & & \\
\hline & OC3 & .77 & & & \\
\hline & $\mathrm{OC} 4$ & .88 & & & \\
\hline & OC5 & .82 & & & \\
\hline & OC6 & .83 & & & \\
\hline \multirow{2}{*}{$\begin{array}{c}\text { SME } \\
\text { Performance } \\
\end{array}$} & Financial & .95 & \multirow{2}{*}{.899} & \multirow{2}{*}{.965} & \multirow{2}{*}{.931} \\
\hline & Strategic & .98 & & & \\
\hline \multirow{3}{*}{ Financial } & FP1 & .91 & \multirow{3}{*}{.891} & \multirow{3}{*}{.961} & \\
\hline & FP2 & .97 & & & .891 \\
\hline & FP3 & .95 & & & \\
\hline & SP1 & .93 & & & \\
\hline Strategic & SP2 & .95 & .889 & .956 & .877 \\
\hline & SP3 & .93 & & & \\
\hline
\end{tabular}


According to Hoque and Awang (2019), Siddiqui and Hoque (2018), Awang et al. (2017b), and Awang (2015) one way of achieving Discriminant validity is that correlation between independent variables must be less than 0.85 . Second criterion of Discriminant validity is when the diagonal values (i.e. $\sqrt[2]{A V E}$ for the respective construct) in the table will be higher than any values in their rows, and columns respectively then Discriminant validity will be achieved (Fornell \& Larcker, 1981). Since, the value in diagonal is higher than any values in its row and column in Table 2, therefore this study has achieved the discriminant validity for the model.

Table 2

Discriminant Validity Index Summary

\begin{tabular}{cccc}
\hline Construct & EO & OC & SME Performance \\
\hline EO & $\mathbf{0 . 8 6 0}$ & & \\
OC & 0.811 & $\mathbf{0 . 8 2 0}$ & \\
SME Performance & 0.242 & 0.812 & $\mathbf{0 . 9 6 4}$ \\
\hline
\end{tabular}

\subsection{Structural Model}

As shown in Fig. 3, three hypotheses $(\mathrm{H} 1, \mathrm{H} 2, \& \mathrm{H} 3)$ are supported. In $\mathrm{H} 1$, EO has a significant direct effect on SME performance $(\beta=0.248, \mathrm{P}=.001)$. In $\mathrm{H} 2$, EO has a significant direct effect on $\mathrm{OC}(\beta=0.801$, $\mathrm{P}=.001)$, in $\mathrm{H} 3$, where $\mathrm{OC}$ also has a significant direct effect on SME performance $(\beta=0.614, \mathrm{P}=.001)$. The structural model explains $73 \%$ variance in SME performance.

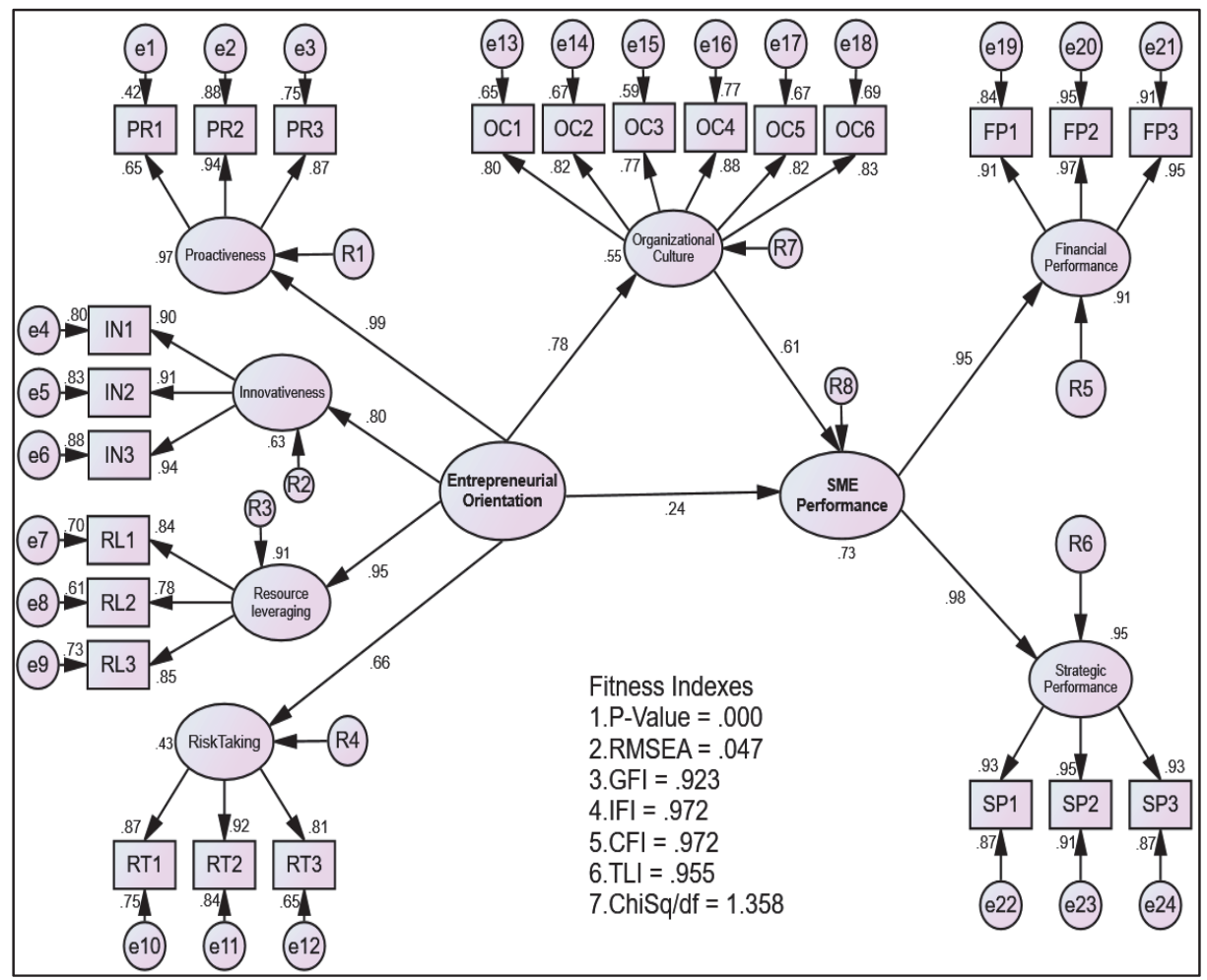

Fig. 3. Standardized Regression Weights for Every Path in the Model

\subsection{Mediation Test}

Fig. 4 shows that indirect effect is $(0.783 \times 0.612) 0.479$ and direct effect is 0.242 . So, indirect effect $>$ direct effect and both EO to OC and OC to SME performance paths are significant. Additionally, direct effect is still significant though mediator enters into the model. Hence, partial mediation occurs (Awang, 2015). 


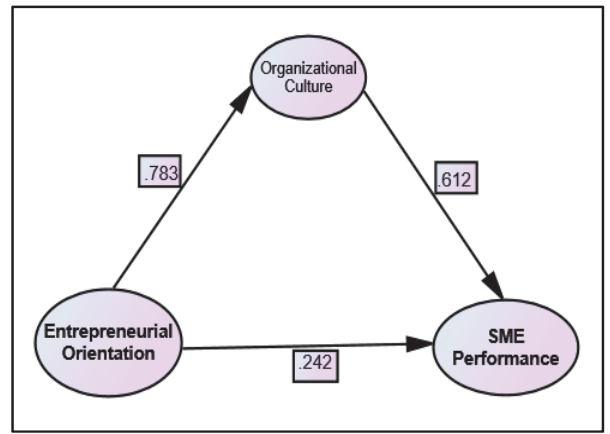

Fig. 4. Standardized Regression Weights for the Model

Bootstrapping: Results of Mediation for Confirmation

Table 3

Bootstrapping Results of Mediation

\begin{tabular}{lcc}
\hline & Indirect Effect & Direct Effect \\
\hline Effect & $\mathbf{0 . 4 7 9}$ & $\mathbf{0 . 2 4 2}$ \\
Bootstrapping p-value & $\mathbf{0 . 0 0 1}$ & $\mathbf{0 . 0 0 2}$ \\
Results of Significance & Significant & Significant \\
Mediation Type & Partial Mediation as direct effect is still significant. \\
\hline
\end{tabular}

Table 3 explained the bootstrapping results of mediation where the beta estimates of both the indirect effect and direct effects of EO on SME performance $(\beta)=0.479$ and 0.242 respectively. It also shows the bootstrapping P-value of indirect and direct effects for the EO on SME performance which are 0.001 and 0.002, respectively. Based on the bootstrapping results in Table 3, it is clear that the $\mathrm{H}_{4}$ of this study is supported by the data of the study and the type of mediation is partial mediation.

\section{Implications of the Study}

This study has expanded our understanding relating to RB theory and outlining the important role of resources as EO as well as this study is the extension on top up earlier studies about the effects of EO on SME performance and the mediating effect of OC on EO and SME performance relationship. This study has also outlined that EO is significant for SME performance prediction. This, thus, this study can work as a directing compass for scholars of entrepreneurship arena to understand what further empirical associations they could possibly bring towards the SME performance and its sustanability. Likewise, the findings highlight an important arena for entrepreneurship to focus and unleash how through effective EO, SME can gain better performance. From this study, policy makers or government can get directions for policy or decision making concerning SMEs in Bangladesh. In parallel, the present study has outlined that EO is essential and decisive for SME in order to get better performance through positive organizational culture. This study has also outlined a new arena of research for researchers to see how organizational culture intervene to explain the relationship between EO and SME performance and it has made a notable stride and outline that organizational culture has a strong intervening role in the relationship between EO and Bangladeshi SME performance.

\section{Limitations and Scope for Future Studies}

Despite the significant results and notable implications, this study also has some limitations. At first, the study used cross-sectional research design which at times restricts from drawing causal explanations. In this regard, longitudinal research study could be a prominent arena for future scholars on the framework to see how EO link with SME performance following the mediation of organizational culture and strengthen the findings of the present study as well. In addition, to this, it is essential to understand that there is a need for robust underlining of prospects that could help to improve organizational culture which resulting to get better SME success. Accordingly, since the present study only examined EO, future 
scholars may attempt to test the impact of other entrepreneurial prospects like market orientation, relationship marketing, competitive advantage and sustainable SME performance and the intervening role in their association.

\section{Conclusion}

The present study has provided empirical confirmation towards the concept of SME performance through outlining how EO can influence and organizational culture can intervene. This study found a positive relationship between EO and SME performance whereby, it also found organizational culture partially mediating this relationship. The findings provide evidence to support the explanations of conservation of RB Theory and how entrepreneur's positive behaviors could be an influential issue for SME success. The study has also forwarded important implications for scholars and practitioners to help facilitate their understanding and comprehension regarding EO, SME performance, and organizational culture perceptions. The findings have empirically strived to guide the SME policy makers as well as future researchers to see the role of EO \& OC to gain better SME performance, especially in the emerging country.

\section{References}

Ahmed, M. U. (2001). Globalization and competitiveness of Bangladeshi Small Scale Industries (SSIs): An analysis of the prospects and challenges. CPD/UPL published, Bangladesh facing the Challenges of Globalization, IRDB. p:2.

Alauddin, MD., \& Chowdhury, M. M. (2015). Small and Medium Scale Enterprise in Bangladesh prospects and challenges. Global Journal of Management and Business Research: Finance, 15(7), 1-9.

Al-Dhaafri, H. S., Al-Swidi, A. K., \& Yusoff, R. Z. B. (2016). The mediating role of total quality management between the entrepreneurial orientation and the organizational performance. The TQM Journal, 28(1), 89-111.

Aminul. M., \& Shariff, M. N. M. (2015). Influence of strategic orientation on SMEs access to finance in Nigeria. Asian Social Science, 11, 298-309.

Awang, Z. (2015). SEM made simple: A Gentle Approach to Learning Structural Equation Modeling. Bandar Baru Bangi: MPWS Rich Resources.

Awang, Z., Ahmed, U., Hoque, A. S. M. M., Siddiqui, B. A., Dahri, A. S., \& Muda, H. (2017a). The Mediating Role of Meaningful Work in the Relationship Between Career Growth Opportunities and Work Engagement. International Academic Conference on Business and Economics (IACBE 2017), Faculty of Economics and Management Sciences (FESP), Universiti Sultan Zainal Abidin (UniSZA), October 07-08.

Awang, Z., Hoque, A. S. M. M., Muda, H., \& Salleh, F. (2017b). The Effects of Crowdfunding on Entrepreneur's Self-Belief. International Academic Conference on Business and Economics (IACBE 2017), Faculty of Economics and Management Sciences (FESP), Universiti Sultan Zainal Abidin (UniSZA), October 07-08.

Bangudu, O. (2013). Nigeria's Operating Environment for Businesses has been difficult. Retrieved June 18, 2018, from http://www.premiumtimesng.com/business/145725

Beattie, S. (2016). Which Entrepreneurial Traits are the Most Critical in Determining Success? Otago Management Graduate Review, 14, 13-20.

Berson, Y., Oreg, S., \& Dvir, T. (2005). Organizational culture as a mediator of CEO values and organizational performance. Academy of Management, 1-9.

Cameron, K. S., \& Quinn, R.E. (2006). Diagnosing and changing organizational culture: based on the competing values framework (2nd edition). Wesley publishing company, Inc.

Child, J. (1972). Organizational structure, environment and performance: The role of strategic choice. Sociology, 6(1), 1-22.

Chirico, F., \& Nordqvist, M. (2010). Dynamic capabilities and transgenerational value creation in family firms: The role of organizational culture. International Small Business Journal, 28(5), 487-504. 
Chow, I. H. (2012). The roles of implementation and organizational culture in the HR performance link. The international Journal of Human Resources Management, 23(15), 3114-3132.

Chow, I. H. S. (2006). The Relationship Between Entrepreneurial Orientation and Firm Performance in China. Advanced Management Journal, 71(3), 11-20.

Chowdhury, M. S., Islam, R., \& Alam, Z. (2013). Constraints to the development of small and medium sized enterprises in Bangladesh: An empirical investigation. Australian Journal of Business and Applied Sciences, 7(8), 690-696.

Coulthard, M. (2007). The Role of Entrepreneurial Orientation on Firm Performance and the Potential Influence of Relational Dynamism. Journal of Global Business and Technology, 3(1), 29-39.

Covin, J. G., \& Slevin, D. P. (1989). Strategic management of small firms in hostile and benign environments. Strategic Management Journal, 10(1), 75-87.

Covin, J., \& Wales, W. (2012). The measurement of entrepreneurial orientation. Entrepreneurship Theory Practice, 36(4), 677-702.

Davood, G., \& Morteza, M. (2012). Knowledge Management capabilities and SMEs organizational performance. Journal of Chinese Entrepreneurship, 4(1), 35-49.

Don, E. (2006). Theory of performance. Retrieved from www.webpages.uidaho.edu/ele/scholars/

results/workshops/facilitators institute/theory\%20of\%20Performance.pdf (Accessed on $12^{\text {th }} \mathrm{June}, 2018$ )

Duke, J., \& Edet, G. H. (2012). Organizational culture as a determinant of non - governmental organization performance: Primer evidence from Nigeria. International Business and Management, 4(1), 66-75.

Fiol, C. M. (1991). Managing culture as a competitive resource: An identity-based view of sustainable competitive advantage. Journal of Management, 17(1), 191-211.

Fletcher, D., Melin, L., \& Gimeno, A. (2012). Culture and values in family business: A review and suggestions for future research. Journal of Family Business Strategy, 3(3), 127-131.

Fornell, C., \& Larcker, D. F. (1981), Structural equation models with unobservable variables and measurement error: Algebra and statistics. Journal of Marketing Research, 18(3), 328-388.

Goel, S., \& Jones, R. J. (2016). Entrepreneurial exploration and exploitation in family business a systematic review and future directions. Family Business Review, 29(1), 94-120.

Hartsfield, S., Johansen, D., \& Knight, G. A. (2008). Entrepreneurial Orientation, Strategy, and Marketing Capabilities in the Performance of Born Global Firms. International Business: Research Teaching and Practice Journal of the AIB-SE, 2(1), 12-38.

Hoque, A. S. M. M., \& Awang, Z. (2016a). The Sway of Entrepreneurial Marketing on Firm Performance: Case of Small and Medium Enterprises (SMES) in Bangladesh, Terengganu International Business and Economics Conference (TiBEC-V), Terengganu, Universiti Teknologi Mara (UiTM), pp. 174-194.

Hoque, A. S. M. M., \& Awang, Z. (2016b). Exploratory Factor Analysis of Entrepreneurial Marketing: Scale Development and Validation in the SME context of Bangladesh, International Social Sciences and Tourism Research Conference, Terengganu, UniSZA, pp. 20-22.

Hoque, A. S. M. M., \& Awanga, Z. (2016c). The Impact of Marketing Strategy on Small and Medium Scale Enterprises (SMEs): Case Study in Bangladesh. International Postgraduate Research Conference (IPRC 2016), Universiti Sultan Zainal Abidin (UniSZA), Gong Badak Campus, Kuala Terengganu, Malaysia, October 8-10.

Hoque, A. S. M. M. (2018).Does government support policy moderate the relationship between entrepreneurial orientation and bangladeshi SME performance? A SEM approach. International Journal of Business Economics and Management Studies, 6(3), 37-59.

Hoque, A. S. M. M., \& Awang, Z. (2019). Does gender difference play moderating role in the relationship between entrepreneurial marketing and Bangladeshi SME performance? Accounting, 5(1), 35-52.

Hoque, A. S. M. M., Awang, Z., \& Ghani, N. A. (2016). Conceptual Model for Quality of Life in the Perspective of Social Entrepreneurship. International Conference on Science, Engineering, Management and Social Science (ICSEMSS 2016), Universiti Teknologi Malaysia (UTM), Johor Bahru, Malaysia, October 6-8. 
Hoque, A. S. M. M., Awang, Z., \& Salam, S. (2017a). The Effects of Relationship Marketing on Firm Performance: Small and Medium Enterprises (SMEs) in Bangladesh, 1st International Conference on Business and Management (ICBM-2017), BRAC Business School (BBS), BRAC University, Dhaka, Bangladesh, September 21-22.

Hoque, A. S. M. M., Awang, Z., \& Siddiqui, B. A. (2017b). Technopreneurial Intention among University Students of Business Courses in Malaysia: A Structural Equation Modeling. International Journal of Entrepreneurship and Small \& Medium Enterprise (IJESME), 4, 1-16.

Hoque, A. S. M. M., Awang, Z., Baharu, S. M. A. T., \& Siddiqui, B. A., (2018a). Upshot of Generation 'Z' Entrepreneurs' E-lifestyle on Bangladeshi SME Performance in the Digital Era. International Journal of Entrepreneurship and Small \& Medium Enterprise (IJESME), 5(July).

Hoque, A. S. M. M., Awang, Z., Jusoff, K., Salleh, F., \& Muda, H. (2017c). Social Business Efficiency: Instrument Development and Validation Procedure using Structural Equation Modelling, International Business Management, 11(1), 222-231.

Hoque, A. S. M. M., Awang, Z., Muda, H., \& Salleh, F. (2018b). Ramification of crowdfunding on Bangladeshi entrepreneur's self-efficacy. Accounting, 4(4), 129-138. ]

Hoque, A. S. M. M., Awang, Z., Siddiqui, B. A., \& Sabiu, M. S. (2018c). Role of Employee Engagement on Compensation System and Employee Performance Relationship among Telecommunication Service Providers in Bangladesh. International Journal of Human Resource Studies, 8(3), 19-37.

Hoque, A. S. M. M., Gwadabe, U. M., \& Rahman, M. A. (2017d). Corporate Entrepreneurship Upshot on Innovation Performance: The Mediation of Employee Engagement. Journal of Humanities, Language, Culture and Business, 1(6), 54-67.

Hoque, A. S. M. M., Siddiqui, B. A., \& Awang, Z. (2018d). Technopreneurial Competency Effect on Technology-based SME Performance: A Structural Equation Modelling on Bangladeshi SMEs. International Journal of Entrepreneurship and Small \& Medium Enterprise (IJESME), 5(July).

Hoque, A. S. M. M., Siddiqui, B. A., Awang, Z., \& Baharu, S. M. A. T. (2018e). Exploratory Factor Analysis of Entrepreneurial Orientation in the Context of Bangladeshi Small and Medium Enterprises (SMEs). European Journal of Management and Marketing Studies, 3(2), 81-94.

Hussain, J., Ismail, K., \& Shah, F. A. (2015). The effect of market and Entrepreneurial Orientation on Organizational Performance: Study of Malaysian SMEs. City University Research Journal, 5(2), 203218.

Ibrahim, M. I., Keat, O. Y., \& Abdul-Rani, B. S. H. (2017). Government Support Policy as a Potential Moderator on the Relationship between Entrepreneurial Orientation, Contemporary Marketing and SMEs Performance in Nigeria a Proposed Framework. Arabian Journal of Business and Management Review, 6(10), 32-42.

Ibrahim, N. I., \& Masud, A. (2016). Moderating role of entrepreneurial orientation on the relationship between entrepreneurial skills, environmental factors and entrepreneurial intention: A PLS approach. Management Science Letters, 6(3), 225-236.

Idar, R., \& Mahmood, R. (2011). Entrepreneurial and Marketing Orientation Relationship to Performance: The SME Perspectives. Interdisciplinary Review of Economics and Management, 1(2), 1-8.

Kantur, D. (2016). Strategic entrepreneurship: meadiading the entrepreneurial orientation-performance link. Management Decision, 54(1).

Karyeija, G. K. (2012). The Impact of Culture on Performance Appraisal Reforms in Africa: The case of Uganda's Civil Service. Asian Social Science, 8(4), 159 -174.

Kraus, S., Rigtering, J. P. C., Hughes, M., \& Hosman, V. (2012). Entrepreneurial orientation and the business performance of SMEs: a quantitative study from the Netherlands. Review Management Science, 6, 161-182.

Kreiser, P. M., Marino, L. D., Kuratko, D. F., \& Weaver, K. M. (2013). Disaggregating entrepreneurial orientation: the non-linear impact of innovativeness, pro-activeness and risk-taking on SME performance. Journal of Small Business and Economics, 40, 273-291.

Lo, Y. (2012). Managerial Capabilities, Organizational Culture and Organizational Performance: The resource-based perspective in Chinese lodging industry. The Journal of International Management Studies, 7(1), 151-157. 
Lumpkin, G. T., \& Dess, G. G. (1996). Clarifying the entrepreneurial orientation construct and linking it to performance. Academy of Management Review, 21(1), 135-172.

Lumpkin, G. T., \& Dess, G. G. (2001). Linking two dimensions of entrepreneurial orientation to firm performance: The moderating role of environment and industry life cycle. Journal of Business Venturing, 16(5), 429-451.

Mahmood, R., \& Hanafi, N. (2013). Entrepreneurial Orientation and Business Performance of WomenOwned Small and Medium Enterprises in Malaysia: Competitive Advantage as a Mediator. International Journal of Business and Social Science, 4(1), 82-90.

Mandy, M. K. (2009). The Relationship between Innovativeness and the Performance of small and Medium-size Enterprises (SMEs)of Malaysian Manufacturing Sector. International Journal of Management and Innovation, 1(2), 1-14.

Miller, D. (1983). The correlates of entrepreneurship in three types of firms. Management Science, 29(7), 770- 791.

Mintzberg, H. (1973). Strategy-making in three modes. California Management Review, 16(2), 44-53.

Mitchell, R. K., Smith, B., Seawright, K. W., \& Morse, E. A. (2000). Cross-cultural cognitions and the venture creation decision. Academy of Management Journal, 43, 974-993.

Morgan, N. A., Kaleka, A., \& Katsikeas, C. S. (2004). Antecedents of export venture performance: A theoretical model and empirical assessment. Journal of Marketing, 68, 90-108.

Mujeeb, E., \& Ahmad, M.S. (2011). Impact of organizational culture on performance management practices in Pakistan. International Management Review, 7(2), 52-57.

Naldi, L., Nordqvist, M., Sjoberg, K., \& Wiklund, J. (2007). Entrepreneurial Orientation, Risk Taking, and Performance in Family Firms. Family Firm Journal, 20(1), 33-47.

Nijssen, E. J. (2017). Entrepreneurial marketing: an effectual approach. Taylor \& Francis.

Obaji, N. O., \& Olugu, M. U. (2014). The Role of Government Policy in Entrepreneurship Development. Science Journal of Business and Management, 2(4), 109-115.

Obiwuru, T. C., Okwu, A. T., Akpa, V. O., \& Nwankwere, I. A. (2011). Effects of Leadership Style on Organizational Performance: A survey of selected Small Scale Enterprises in IKOSI_KETU council development area of Lagos State, Nigeria. Australian Journal of Business and Management Research, 1(7), 100-111.

Pearce, J. A., Fritz, P., \& Davis, P. S. (2010). Entrepreneurial orientation and the performance of religious congregations as predicted by rational choice theory. Entrepreneurship Theory and Practice, 34(1), 219-248.

Rauch, A., Wiklund, J., Lumpkin, G. T., \& Frese, M. (2009). Entrepreneurial orientation and business performance: An assessment of past research and suggestions for the future. Entrepreneurship Theory and Practice, 33(3), 761-787.

Richard, O. C., Barnett, T., Dwyer, S., \& Chadwick, K. (2004). Cultural diversity in management, firm performance, and the moderating role of entrepreneurial orientation dimensions. Academy of Management Journal, 47(2), 255-266.

Rugraff, E., \& Hansen, M. W. (2011). Multinational Corporations and Local Firms in Emerging Economies. University of Chicago Press Economics Books, University of Saparito.

Santos, J. B., \& Brito, L. A. L. (2012). Toward a subjective measurement model for firm performance. Brazilian Administration Review (BAR), 9(6), 95-117.

Schein, E. H. (2004). Organizational culture and leadership (3rd edition). John Wiley \& Sons, San Francisco.

Schumpeter, J. A. (1942). Capitalism, socialism and democracy. Harper and Brothers, New York.

Siddiqui, B. A., \& Hoque, A. S. M. M. (2018). Innovation Performance of Internet Service Providers in Bangladesh: The Sway of Corporate Entrepreneurship. International Journal of Entrepreneurship and Small \& Medium Enterprise (IJESME), 5(July).

Slater, M., \& Narver, J. C. (2000). The positive effect of a market orientation on business profitability: a balanced replication. Journal of Business Research, 48, 69-73.

Slater, S. F., Olson, E. M., \& Finnengan, C. (2011). Business strategy, marketing organizations culture and performance. Marking Letters, 22, 227-242. 
Smith, T. M., \& Reece, J. S. (1999). The Relationship of Strategy, Fit Productivity, and Business Performance in a Services Setting. Journal of Operations Management, 17(2), 145-161.

Stam, W. \& Elfring, T. (2008). Entrepreneurial orientation and new venture performance: the moderating role of intra- and extra-industry social capital. Academic Management Journal, 51(1), 97-111.

Swierczek, F. W., \& Ha, T. T. (2003). Entrepreneurial orientation, uncertainty avoidance and firm performance. Entrepreneurship and Innovation, (February), 46-58.

Tang, J. Z., Marino, Y., Zhang, Q. L., \& Li, T. (2008). Exploring an Inverted U-Shape Relationship between Entrepreneurial Orientation and Performance in Chinese Ventures. Entrepreneurship Theory and Practice, 32(1), 219-239.

Tidor, A., Gelmereanu, C., Baru, P., \& Morar, L. (2012). Diagnosing organizational culture for SME performance. Economics and Finance, 3, 710-715.

Tihanyi, L., Griffith, D. A., \& Russell, C. J. (2005). The effect of cultural distance on entry mode choice, international diversification, and MNE performance: A meta-analysis. Journal of International Business Studies, 36, 270-283.

Van de Ven, A. H., \& Poole, M. S. (1995). Explaining development and change in organizations. Academy of Management Review, 20(3), 510-540.

Venkatraman, N. (1989) Strategic orientation of business enterprises: the construct, dimensionality and measurement. Management Science, 35(8), 941-962.

Wales, W. J., Gupta, V. K., \& Mousa, F. I. (2011). Empirical research on Entrepreneurial orientation: An assessment and suggestion for future research. International Small Business Journal, 1-27.

Walter, A., Auer, M., \& Ritter, T. (2006). The impact of network capabilities and entrepreneurial orientation on university spin-off performance. Journal of Business Venture, 21(4), 541-567.

Weimei, Z., \& Feng-e, T. (2012). Analysis of Performance Management in Small and Medium Enterprises. 2nd International Conference on Mechanical, Industrial, and Manufacturing Engineering IERI. Procedia, 1, 8-12.

Wiklund, J., \& Shepherd, D. (2003). Knowledge-based resources, Entrepreneurial Orientation, and the performance of small and medium-sized businesses. Strategic Management Journal, 24(13), 13071314.

Xenikou, A., \& Simosi, A. (2006). Organizational culture and transformational leadership as a predictors of business unit performance. Journal of Managerial Psychology, 21(6), 566- 579.

Yang, M. (2018). International entrepreneurial marketing strategies of MNCs: Bricolage as practiced by marketing managers. International Business Review, 1-12.

Zahra, S. A., Hayton, J. C., \& Salvato, C. (2004). Entrepreneurship in family vs. nonfamily firms: A resource-based analysis of the effect of organizational culture. Entrepreneurship Theory and Practice, $28(4), 363-381$.

Zainol, F. N. (2010). Cultural background and firm performance of Indigenous Malay family firms in Malaysia: The role of entrepreneurial orientation as a mediating variable. Journal of Asia Entrepreneurship and Sustainability, 6(1), 3-19.

Zeebaree, M. R. Y., \& Siron, R. B. (2017). The Impact of Entrepreneurial Orientation on Competitive Advantage Moderated by Financing Support in SMEs. International Review of Management and Marketing, 7(1).

Zhang, Y., \& Zhang, X. (2012). The effect of entrepreneurial orientation on business performance A role of network capabilities in China. Journal of Chinese Entrepreneurship, 4(2), 132-142.

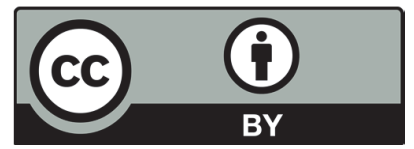

(C) 2018 by the authors; licensee Growing Science, Canada. This is an open access article distributed under the terms and conditions of the Creative Commons Attribution (CCBY) license (http://creativecommons.org/licenses/by/4.0/). 